\title{
THE FEMALE CONSUMER, WHO SHE IS, WHO SHE WANTS TO BE AND WHO SHE CANNOT BE AS A CONSUMER
}

\begin{abstract}
This article demonstrates who a woman is as a consumer and how she strives to fulfill the requirements of the world of consumption. The world of consumption is a form of living according to the new moral imperative of a "fun reality." For the female consumer professional success is very important. The family becomes secondary because a family represents many forms of limitation and restriction and this is not seen as something good in the world consumption. A woman - consumer, always beautiful and well-dressed has no time for a deepened reflection over her life. She is buying her happiness - any purchase of a beautiful object should make her happy; the same as a man - consumer. In the world of consumption there is not much place for the reflection over important matters. The world of consumption is limited to things and material values, the emphasis is put on what is useful and beautiful. This is why a woman is being all the time under a pressure of being beautiful and young, she cannot be tired and she is not allowed to look badly, thus she loses too much then. To have a significance in the world of consumption a woman should be beautiful, i.e. slim and young. A woman in the world of consumption is defined by her body, not by her knowledge, abilities or skills. Subordination to the principles of the world of consumption makes a woman a beautifully wrapped object. A happiness in terms of the world of consumption can be achieved by a woman - consumer only temporarily, while with the time passing by and natural process of aging there would be fewer and fewer place for a woman consumer in the world of consumption.
\end{abstract}

Keywords: woman, consumer society, beauty.

Who is the female consumer? Who does she want to be and who is it that she cannot be? This is the question that, in the context of the modern society of consumption, has a different answer than is normally formed in this type of society. A woman consumer is subject to the principles and rules of the world and society of consumption. The purpose of this text is to show who the woman is that has become a consumer. At the same time the answer to this question will show who the female consumer should not be if she wants to remain in compliance with the requirements of the world and society of consumption. A separate question is whether in becoming a consumer a woman is able to be happy? Happiness is recognized as one of the main values of the world of consumption. Is the woman consumer the woman who she would like to be? Does consuming provide longlasting happiness for her? We can to begin with the hypothesis, that a woman as a consumer is happy in the world of consumption but for only a certain amount of time which, in comparison to her entire lifetime, is quite short. What's more, being a consumer

\footnotetext{
${ }^{1}$ Dr hab., (Assosiated Professor) Head of the Chair Social and Political Philosophy, Department of Philosophy, Univesitry John Paul II in Cracov, e-mail: joanna.mysona.byrska@ upjp2.edu.pl
} 
can deprive a woman of being herself in the fullest possible sense. The woman consumer seems to be limited and subordinated to the demands of the world of consumption, which is not always good for her. To answer these questions and prove the above hypothesis first an overview of the world of consumption must be presented and then a description of the woman who is living in this world and is or becomes a consumer.

The world that surrounds the person living in modern Europe is one that is rich and full of diverse goods. The world of affluence and consumption is accessible to all who have sufficient financial resources. The most important thing in this world is consumption, and the level at which one consumes speaks to the value and social status of the individual. Because the value of the individual is determined by the level of consumption, that is, property, clothing, etc. it is hardly surprising that in the world and society of consumption what one has to show is what counts above all else. External things are preferred - everything should be on display. The old adage: "fine feathers make fine birds" is more and more significant in the world of consumption. Packaging, what you see on the outside, is important, even more important than what is unseen or intangible. Zygmunt Bauman simply says that in a world and in a society of consumption aesthetics appears in the place of ethics ${ }^{2}$, which means that aesthetic values play a major role. At the same time it should be noted that aesthetic values have always been prized, people like beautiful things, they like to surround themselves with them and derive pleasure from them. It seems that there is nothing wrong with that. The problem begins when aesthetic values prevail over ethical values and aesthetics displaces ethics. This means that rather than seek the broadly understood "good" a person strives for beauty instead. In other words, we can say very simply, something can be pretty and not necessarily good. This means the entire world has had a change in perception. Also, what it means to be a woman and how a woman should fulfill her role has changed as well.

One of the new values that has appeared in the esthetics of the world of consumption is entertainment, or a specialist who tells the consumer in what way to be entertained or whether the entertainment is suitable ${ }^{3}$. Spontaneous fun is not considered valuable because fun must be appropriate to the world of consumption. In accordance with the principles of the world of consumption, fun is based on pleasure ${ }^{4}$. The principle of pleasure, which has been known for centuries, is strongly associated with fun and has become one of the leading values in the world of consumption ${ }^{5}$. Fun must be had in accordance with a plan that has been prepared by a specialist, it might be very extravagant and exclusive, that is, expensive.

A characteristic of the world in which fun is an important value, is the emergence of an ethos of free time in place of the ethos of hard work for the common good. This free time is a time devoted to fun, which is very valuable and continues to become more valuable. Hard work is permitted only if it brings the financial resources to enable a person to have fun during their free time.

When it comes to work, according to the requirements of the world of consumption, it should be primarily interesting because interesting is a new value. Those who have

\footnotetext{
${ }^{2}$ Z. Bauman, Praca konsumpcjonizm i nowi ubodzy, WAM, Kraków 2005, p. 67 i n.

3 J.E. Combs, Świat zabawy. Narodziny wieku ludycznego, UW, Warszawa 2011, p. 76-77.

${ }^{4}$ Ibidem, p. 18.

5 J. Baudrillard, Społeczeństwo konsumpcyjne. Jego mity i struktury, Sic! Warszawa 2006, p. 179.
} 
reached the appropriate level of consumption can do this ${ }^{6}$. Virtue in the world of consumption is spending money not making it, because if a person has money they do not need to work and should have fun. Women have always been good at spending money! In the world of the consumption they are allowed to spend money and in this respect they can do it calmly and in the same way men do. In the world of consumption this behavior is strongly supported and encouraged - in this way the fundamental value of the world of consumption is realized: spend with all your might.

Who is a woman in the world of consumption? She is certainly a consumer. It seems to be that a female consumer is different from a male consumer.

First, a woman - as a consumer, is to pursue the fundamental task that the world of consumption poses to a person, that is, to consume, and preferably by not thinking too much about it because any reflection may endanger carefree consumption. In the course of reflection one may ask whether a purchase makes sense or if an object is needed, etc.

Second, a woman who wants to meet the requirements of the world of consumption must be pretty. What counts above all else is that which is external and the female consumer fulfills this requirement. What it means to be beautiful is also precisely defined. The canon of beauty in the world of consumption is not nice to the woman who has been given a full figure. A symbol of beauty in the world of consumption is the Barbie doll. She is very thin, with extremely long legs, a narrow waist and large breasts. According to this canon of beauty a woman is beautiful if she is slim (not too skinny), young or at least looks young, free (that is, without obligations), happy and has a career. A beautiful woman is one who works, she is definitely not a housewife or mother. Female beauty seems to be related to occupational activity.

In the world of consumption appearance is very important. Joel Bakan highlights this when he writes:

- (...) the value of the person is evaluated solely on the basis of her sexual allure or behavior, without other characteristics;

- the obligatory standard for the physical attractiveness of a person (narrowly defined) is equal to being sexy;

- a person is objectified from the sexual point of view - this is done for the benefit of serving someone else's sexual desires and is not seen as a person capable of independent action and decision-making;

- sexuality is imposed in an inappropriate manner (this applies especially to children $)^{7}$.

In the world of consumption, according to the above citation, one must look good, that is thin, young and healthy ${ }^{8}$. A beautiful woman is sexy and if she isn't sexy she's not beautiful.

${ }^{6}$ D. Grabowski, Miejsce pracy w kulturze konsumpcji. Etos pasjonujacej i interesujacej pracy jako forma jej konsumpcji, [in:] M. Górnik-Durose, A.M. Zawadzka, „W supermarkecie szczęścia. O różnorodności zachowań konsumenckich w kontekście jakości życia”, Difin, Warszawa 2012, p. 56-77.

${ }^{7}$ J. Bakan, Dzieciństwo w oblężeniu. Latwy cel dla wielkiego biznesu, Muza, Warszawa 2013, p. 73, cf. J. Mysona Byrska, Dobry konsument - zty obywatel, [in:]: ed. D. Probucka, „Etyka i dobro”, UP, Kraków 2015, p. 213-221.

${ }^{8}$ J. Baudrillard, Społeczeństwo konsumpcyjne. Jego mity i struktury, op. cit., p. 189-191. 
Who is the pretty, thin, forever young female consumer? She may be a fashionable trophy wife who is next to an equally attractive man - the female consumer provides beauty to his high status and does not speak, because she only has to look a certain way. It is not received well when the trophy wife speaks up, it is not her job to speak her opinion, she should admire her wonderful man, next to whom she gets to stand and be pretty.

A woman in the world of consumption can also be a wonderful businesswoman who looks stunning and has a wonderful career thanks to her highly specialized skills.

According Lesława Hostyńskiego a woman, and especially her femininity, manifests itself in contemporary culture in several forms. A woman is seen according to these forms: sexpot, anorexic, bodybuilder, cyber-girl, feminist, businesswomen, femme fatale, artist and, finally, patroness of the hearth. In the world of consumption, only the first four count ${ }^{9}$. A sexpot is a woman who is waiting for her macho man. While waiting she takes care of herself by spending time in luxurious spas, at the beautician, hairdresser, etc. The anorexic strives for perfection and wants to look like a fashion icon, like Angelina Joli for example. She never feels slim enough and this is the most important thing for her. She is always on some kind of fashionable diet and is eager to visit the organic store. She does not have to actually suffer from anorexia it is sufficient that she is extremely sensitive about her weight and lean appearance. The bodybuilder is as strong as a man in everything she does and wants equality in every respect. At the same time she is dreaming about a strong man who will be able to meet her expectations and is as great as she is.

All of the examples given by Hostyński have one thing in common. A woman in the world of consumption is defined by her body and not her soul ${ }^{10}$ and, therefore, must strive with all her might to take care of her body. This body, specifically its appearance, decides who the woman is as a consumer. Therefore, she will spend a lot of time on her body.

The essence of femininity, that is the ability to be a mother, is problematic in the world of consumption because pregnancy "spoils the body." A pregnant woman gets fatter and for a female consumer this can be a problem. The woman who becomes a mother, finds out from the mass media, as well as her colleagues, that she should immediately get back to her former weight. Immediately, that is, the sooner the better, but it should not take longer than three months. There are always photos of celebrities just after childbirth who look even thinner than before. A female consumer is subject to the opinion of the media the world is a world of consumption externality and the woman tries to meet that ideal. When she fails she is unhappy.

According to Hostyńskiego the quintessential female consumer is Ally McBeal, the heroine of the famous TV show. Ally has a career, is independent financially, slim and pretty all in line with the requirements of the world of consumption. As she says in one episode, she doesn't need a man she wants one. She does not need a man because she is an independent, post-feminist woman - the epitome of the female consumer. However, she is single, not because she wants to be, she doesn't consciously choose to be single. She meets the requirements of the world of consumption perfectly. But she has not found the right man who will stay with her permanently. She has many partners who prove to be no match for her. And this is not a feminist choice ${ }^{11}$. Ally is the victim of her own success as

\footnotetext{
${ }^{9}$ L. Hostyński, Karnawat czy post? O moralnych zagrożeniach $w$ świecie konsumpcji, PWN, Warszawa 2015, p. 246.

${ }^{10}$ Ibidem, p. 246.

11 Ibidem, p. 245.
} 
a woman, as an ideal consumer, before which men flee, despite the fact that she is what every women dreams of becoming, because she is too perfect in the world of consumption.

The woman consumer is confident, liberated, independent, and determined. She is also self-centered and thus is able to achieve success. It seems that to present a masculine attitude and complement it with feminine beauty can be used as a tool for success. A beautiful appearance gives one confidence - or so preaches the media.

The woman consumer consumes. She should, after all, do nothing else - this is the basic task of every consumer and therefore it is also hers. The integral element of identity is the body and the body determines who the woman is as a consumer. Hostyński believes that the woman lives in a world of a new moral imperative. It is the imperative of a "fun morality" - used to frame the possibilities of free time ${ }^{12}$. Living under the pressure of such an imperative seems to be very easy - one should play and who doesn't like that? In actual practice a life that requires constant fun, looking great and smiling all the time turns out to be tiresome. Ordinary lying on the hammock with my aunt in the garden does not meet the basic requirement of uniqueness - and this should be the entire life of the female consumer.

The female consumer, like Ally McBeal, is looking for a partner. Selecting the right partner in the world of consumption is also subject to certain rules. First of all, remember that this is also a consumer choice and should be safe. Risks and changes in the world of consumption are undesirable. According to Zygmunt Bauman, the other person is also a commodity, an object for selection, like everything else. He or she is designed to raise the status of the person choosing him or her. What matters is the external, the other person is fully objectified and commodified ${ }^{13}$. Finances determine the relationship between two people in the world of consumption - both sides in the relation are to reap certain benefits by being together so that their status in society increases. Selecting the right partner should not be risky, it is a choice like a purchase and if the product does not meet the requirements it can be returned; or if it's broken, discarded ${ }^{14}$. The subjective treatment in this world is not typical and does not fit with existing rules.

For this reason, there are more and more heterosexual relationships, which strongly differ from what was formerly the typical marriage but meet the requirements of the world and society of consumption. The first of this type is a new type of relationship referred to as "dinks" - double income no kids ${ }^{15}$. This is a married couple with no children where both partners are developing careers and a child is seen as a limitation to both spouses. It should be emphasized very strongly that the childlessness is due to a conscious decision and not because of problems with procreation. Childless marriages are not necessarily to be immediately considered as "dinks" it depends on how they perceive having children. The second relationship characteristic of the world of consumption is called LAT - living apart together - spouses live separately but they are married. They have two separate

\footnotetext{
12 Ibidem, p. 234.

${ }_{13}$ Z. Bauman, Konsumowanie życia, UJ, Kraków 2009, p. 22.

${ }^{14}$ Ibidem, p. 20-21.

${ }^{15}$ E. Markowska-Gos, Konsumeryzm a symptomy dezorganizacji rodziny wspótczesnej. Wybrane aspekty, [in:] ed. M. Dziura, E. Wolanin-Jarosz, „Homo consumens”, KUL, Lublin 2014, p. 108.
} 
homes and thus remain independent, but at the same time they are connected with each other. In this type of marriage neither one is limited, at least that is the goal ${ }^{16}$.

Undoubtedly, for a female consumer children are a problem. It is a natural desire to have children. But the child for a female consumer constitutes a threat to her consumer status. It is not only that pregnancy spoils the body in many cases the appearance of a child in the world results in troubles at work or loss of work. A child may pose the threat of poverty for a woman, and not only to the female consumer, if there are no suitable legal protections ${ }^{17}$. According to statistical surveys in Poland, the cost of maintaining a child is about 1000 zloty a month ${ }^{18}$. What is more interesting is that for a man a child does not create the threat of poverty.

The female consumer does not want to become a mother. This has a variety of causes most of which are generated by the characteristics of the world of consumption. Just like Ally McBeal, the woman consumer cannot find a partner who matches her high social status, is a partner / husband who can provide the stability necessary to be able to decide on a child. It is not only financial stability but also life and the broadly understood certainty of tomorrow.

Another anxiety the female consumer faces is the problem of finances. Children cost money and a pregnant woman no longer meets the basic requirements of beauty. She also isn't able to implement the aforementioned imperative of the "fun reality." In thinking about the future it becomes more and more difficult for her to play and certain types of fun are not allowed. For the woman consumer the conception of a child means limitations.

Another problem is the attitude of world of the consumption toward mothers and toward young mothers in particular. It is quite surprising, however, that the value of women as mothers seems to have fallen in the eyes of society, a woman who works has greater value. Professor Zbigniew Mikołejko wrote about what he terms "pram-mothers," described as a young mother with a small child who spends her time in front of the apartment block shouting and smoking cigarettes. For the "pram- mother," the child is her excuse for having a job and doing nothing. She has no better idea for what to do with her life in mind and so, as a result of her desire to escape from the necessity of work and the normal development of a young woman, she decides to have a child. She uses the child as an excuse to demand specific rights ${ }^{19}$. What Mikołejko describes, of course, is only a marginal phenomenon present among young mothers, but the text has some social concerns. The mother of a small child may demand special treatment. Every privilege for one person means restrictions for someone else, and the consumer does not like restrictions. Mikołejko ${ }^{20}$ writes that anxiety about their ranking in the circle of "prammothers" is described as a "warlike, wild and expansive segment of Polish motherhood." It also has an impact on the female consumer's desire to have children since, without a child she is independent, admired, respected and free.

\footnotetext{
${ }^{16}$ E. Markowska-Gos, Konsumeryzm a symptomy dezorganizacji rodziny wspótczesnej. Wybrane aspekty, op. cit., p. 108.

17 Ibidem.

18 Ibidem, p. 110.

${ }^{19}$ Z. Mikołejko, Wózkowe - najgorszy gatunek matki, [in:]: „Wysokie obcasy. Gazeta Wyborcza”, 05.09.2012, http://www.wysokieobcasy.pl/wysokie-obcasy/1,96856,12429251,Wozkowe_nnajgorszy_gatunek_matki.html?disableRedirects=true (accessed: 04.012.2015).

20 Ibidem.
} 
According to Bauman the next concern is job loss, which threatens, each worker who is not a "non-resistance" 21 employee. That is, an employee without obligations, who is completely at the disposal of the company and has no expectations about company loyalty or long lasting stable employment. For an employer, a woman who has a child or plans to have one is not and never will be this type of employee. The employee is the one who is responsible for the quality of her work and her behavior. However no one can guarantee that the child will be healthy, which means that the mother may not be available to work.

Finally, in the era of gender another concern appears. It is a fear backed by messages from the media, a fear, which can be put into the following words: "Is this really a grown man? Or is this really a big baby who is looking to be cared for by a wife / partner?" This is the female consumer's question. She is a liberated, independent, beautiful woman, who is looking for a responsible partner, who meets his as well as her expectations. In the world of consumption the family is also changing radically due to the changes of the female consumer. The family has become as Ewa Markowska - Gos writes, "a contractual relationship of an emotional nature" ${ }^{22}$. The marriage contract is consistent with the requirements of consumerism - all consumer choices are to be safe and bear as little risk as possible. Marriage is seen as a contract between two people that is preceded by a prenuptial agreement, which is there to protect the interests of both parties in the event of a possible divorce. As a result of the prenuptial agreement both sides feel safe financially. Also buying two small apartments rather than one big one is becoming popular. The apartments have separate land and mortgage registers and in case of divorce can easily be divided and the wall, which was originally knocked down, can be rebuilt to separate them. As a result of this, credit is no longer limiting or a reason to prevent divorce. Formally, every apartment has a separate existence and its own credit.

In the world of the consumption there has been a change in the perception of divorce and women are the ones effecting this change. Not so long ago divorce was considered as a final exit, the defeat of life plans. Divorced woman aroused negative feelings and at best pity. Currently, they serve as statistical studies. Women understand divorce as the right to a dignified life, a more interesting studies show that $75 \%$ of women who get divorced are about 24 years old $^{23}$. There is also a growing number of applications in Poland for the annulment of sacramental marriages. Female consumers who do not want to sacrifice at any cost increasingly appreciate freedom and lack of restriction.

If a woman decides to become a wife and mother she must reckon with the fact that her possibilities and freedom to consume and the type play that goes with it will change. As Thorstein Veblen noted, through consumerism woman are able to reach a higher social status, other women are jealous of her; do not give her a family and children as these will only hold her down ${ }^{24}$. Maybe we are dealing with the woman who belongs to the consumer aristocracy, who has enough financial resources that nothing will be a limit for her. The above-described concerns are characteristic of the normal, average consumer, often living on credit, in order to maintain the appropriate status. Of course, we must omit

\footnotetext{
${ }^{21}$ Z. Bauman, Konsumowanie życia, op. cit., p. 15.

${ }^{22}$ E. Markowska-Gos, Konsumeryzm a symptomy dezorganizacji rodziny wspótczesnej. Wybrane aspekty, op. cit., s. 111-113.

${ }^{23}$ Ibidem, p. 114.

${ }^{24}$ T. Veblen, Teoria klasy próżniaczej, Literackie Muza, Warszawa 1998, p. 68-69.
} 
all the values that are implemented in family life. In the world of consumption tangible, measurable and external values come first ${ }^{25}$.

As regards the family, an additional problem for female consumers is that the external perception of the family determines her social status. The children must go to the right school and all members of the household as well as the house should look $\operatorname{good}^{26}$. She, as the woman is responsible for this.

Also daily newspapers and in media targeted at the female consumer provide information and recommendations as to how she should look, what she should do and eat, as well as how she should spend her time if she is to be fashionable, that is pretty, slim and happy. There isn't any information about what her intellectual development should look like. Most women's magazines promote the ideal woman from the perspective of her body - to be slim, young and well groomed ${ }^{27}$. As to the intellectual development of the woman no one, or almost no one, cares. Nihil novi sub sole in the world of consumption, is a basic requirement for women consumers. But an analysis of women's media shows that "the potential reader gets (...) a kind of recipe - knows what is fashionable, where to buy and how much she will have to pay" ${ }^{28}$. In other words, a reader gets exact instructions on how to behave when making her consumer choices, which is dominated by attention to being thin and looking young as the main values ${ }^{29}$. Taking care to ensure a slim silhouette has moved so far, that the fashionable (slim and beautiful) consumer is able to bake two dishes for dinner in one oven - "something light for her, something satisfying for him" - as seen in an advertisement for the duel cook oven by Samsung. Thus she won't get fat, and he won't go hungry. Moreover, it doesn't matter that she doesn't have time to cook the oven is so great that she cannot resist it...

The woman as a consumer (which is the same for a male consumer) is controlled by advertising, which suggests what is worth purchasing and what should be purchased ${ }^{30}$, in order to remain in compliance with the requirements of the world of consumption. For the holidays it is necessary to buy as many gifts as possible, for a vacation, sunscreen, sunglasses, etc., etc.

What women's magazines promote as most important is that a woman should be beautiful. Cosmetics require constant change from season to season as this gives a woman a new beautiful look and the products receive a pseudo-scientific name in order to sell better. The female consumer is created - she is one who is supposed to care about her appearance, to wear the appropriate clothing and accessories - fashionable shoes, bags and jewelry, to use cosmetic innovations and diverse methods of the dieting, because she is certainly too $\mathrm{fat}^{31}$. Jean Baudrillard shows that the body becomes subject to repressive

\footnotetext{
${ }^{25}$ Odnośnie wartości świata konsumpcji zob. J. Mysona Byrska, Nove hodnoty v magickom svete konzumpcie, [in:] ed. I. Mihalikova, „Fyzika a etika VIII. Veda ako kulturny fenomen”, UKF, Nitra 2013, p. 283-291.

${ }^{26}$ E. Markowska-Gos, Konsumeryzm a symptomy dezorganizacji rodziny wspótczesnej. Wybrane aspekty, op. cit., p. 100.

27 S. Królikowska, Kreowanie postaw konsumpcyjnych przez prasę kobieca, [in:] ed. Marian Golka, „W cywilizacji konsumpcji”, UAM, Poznań 2004, p. 146.

${ }^{28}$ S. Królikowska, Kreowanie postaw konsumpcyjnych przez prasę kobieca, op. cit., p. 146.

${ }^{29}$ Ibidem, p. 147.

${ }^{30}$ Ibidem, p. 152

31 Ibidem, p. 154-155.
} 
preoccupation - it must be slim and only as a result of that, is it beautiful ${ }^{32}$. When reading articles about women it is possible to get the impression that the woman who looks like she should does not exist. There is always something to fix even if, as a last resort, it is just to do her making up quickly.

Women's magazines and media present the successful woman as having a professional career and financial success; the role of women as wives, mothers, and housewives seems to be secondary. This is entirely consistent with the principles of the world of consumption. Success in a woman's life is defined primarily as material and professional success. Family roles are only complementary to the image of the woman, who is primarily an active professional. For Baudrillard work at home and dealing with children are not within the "magic white numbers", which prevails in the world of consumption. The "magic white numbers" mean that everything should be profitable, sellable and countable by financial means ${ }^{33}$. The woman should in a magical way, and shortly after returning from work, cook up a wonderful two-course dinner plus desert.

The guaranteed formula for success at work is: young, slim, and beautiful with fashionable clothes and makeup. Women should also eat appropriately, that is according to the prevailing fashion. This also ensures her success because a woman by eating what she is supposed to (and not eating what she isn't supposed to) is showing her modernity and usefulness in the labor market ${ }^{34}$.

In order to achieve success the woman is supposed to concentrate on her body! Baudrillard argues that the contemporary body has become an object of worship, tactic and social ritual - beauty and eroticism are the guiding themes ${ }^{35}$. The beauty of a woman is becoming a religious order, a fundamental value, "a sign of being chosen" ${ }^{36}$. Beauty in the world of consumption is a form of capital, and therefore an unconditional imperative $\mathrm{e}^{37}$. It depends upon taking care of ones body unconditionally and with all ones power.

What occurs is a mandate to have as many things as possible, the more the better: a woman should have a lot of cosmetics, because proves she is a better employee, the more they are used the better she is. It is clearly understood that more adds to the quality ${ }^{38}$ of beauty. Everybody knows more doesn't necessarily mean quality, but the world of consumption adores excess, so for it more, despite everything, is better.

A happy female consumer is a woman who is free, independent, not tied to the kitchen, clean windows or crying children. She is beautiful and sexually liberated. She is a woman of success. She is looking for a partner to help her build a home and will also help in caring for the children and doing the household chores. And this, for the male consumer, may be too difficult because by definition it limits his consumption.

The woman as consumer seems to be a kind of empty shell - only the packaging counts and it is always outdated. Who will the woman consumer be in a few years? Probably because of "packaging" external change is not esteemed by anyone. Of course

\footnotetext{
${ }^{32}$ J. Baudrillard, Społeczeństwo konsumpcyjne. Jego mity i struktury, op. cit., p. 189-190.

33 Ibidem, p. 33.

${ }^{34}$ S. Królikowska, Kreowanie postaw konsumpcyjnych przez prasę kobieca, op. cit., p. 157-158.

35 J. Baudrillard, Społeczeństwo konsumpcyjne. Jego mity i struktury, op. cit., p. 174.

${ }^{36}$ Ibidem, p. 175.

${ }^{37}$ Ibidem.

${ }^{38}$ S. Królikowska, Kreowanie postaw konsumpcyjnych przez prasę kobieca, op. cit., p. 159, J. Baudrillard, Społeczeństwo konsumpcyjne. Jego mity i struktury, op. cit., p. 9-10.
} 
there are exceptions. This has nothing to do with discrimination against women, male consumers have a very similar process and the external is becoming more and more important for them as well. However, it is only men who become increasingly attractive with age that is not a possibility for women in the world of consumption.

A woman - apparently liberated, elegant and reaching for success, in fact, is subordinated to the rules of the world of consumption, which are kind to her as long as she is able to remain young and beautiful. She would like to always be beautiful, eternally young and unique. She would like to be a successful woman. But in most cases she is unremarkable, normal, average, and the colorful world of consumption constantly shows her that she should step up her efforts in the pursuit of external perfection. A woman is not able to reach the consumer ideal of the sexy women, because it remains constantly at her fingertips, just out of reach for the moment. It is temporary, extremely fleeting, and in a season the ideal has changed.

Compliance to the rules of the world of consumption makes a woman flat figured and limited in how she looks, fashionably dressed with a studied smile on her face. Is the female consumer happy, or can she achieve real success in the world of consumption? It seems that she can under the condition that she is good enough on the outside. But it is a momentary success that is fragile. Just like everything in the world of consumption it is transient.

\section{REFERENCES}

[1] Bakan J., Dzieciństwo w oblężeniu. Łatwy cel dla wielkiego biznesu, Muza, Warszawa 2013.

[2] Baudrillard J., Społeczeństwo konsumpcyjne. Jego mity i struktury, Sic! Warszawa 2006.

[3] Bauman Z., Konsumowanie życia, UJ, Kraków 2009.

[4] Bauman Z., Praca konsumpcjonizm i nowi ubodzy, WAM, Kraków 2005.

[5] Combs J.E., Świat zabawy. Narodziny wieku ludycznego, UW, Warszawa 2011.

[6] Grabowski D., Miejsce pracy w kulturze konsumpcji. Etos pasjonujacej i interesujacej pracy jako forma jej konsumpcji, [in:] ed. M. Górnik-Durose, A.M. Zawadzka, „W supermarkecie szczęścia. O różnorodności zachowań konsumenckich w kontekście jakości życia”, Difin, Warszawa 2012, p. 56-77.

[7] Hostyński L., Karnawał czy post? O moralnych zagrożeniach $w$ świecie konsumpcji, PWN, Warszawa 2015.

[8] Królikowska S., Kreowanie postaw konsumpcyjnych przez prasę kobieca, [in:] ed. M. Golka, „W cywilizacji konsumpcji”, UAM, Poznań 2004, p. 145-162.

[9] Markowska-Gos E., Konsumeryzm a symptomy dezorganizacji rodziny współczesnej. Wybrane aspekty, [in:] ed. M. Dziura, E. Wolanin-Jarosz, „Homo consumens', KUL, Lublin 2014, p. 97-118.

[10] Mysona Byrska J., Dobry konsument - zły obywatel, [in:]: ed. D. Probucka, „Etyka i dobro", UP, Kraków 2015, p. 213-221.

[11] Veblen T., Teoria klasy próżniaczej, Literackie Muza, Warszawa 1998. 


\section{KOBIETA - KONSUMENTKA. KIM JEST, KIM CHCE BYĆ I KIM NIE MOŻE BYĆ KONSUMENTKA}

W artykule omawiam kim jest kobieta jako konsumentka oraz jakie wymagania stawia przed kobietą świat konsumpcji. Świat konsumpcji wymaga od jednostek realizacji nowego imperatywu moralnego zwanego "fun reality" (rzeczywistość zabawy). Dla kobiety konsumentki bardzo ważny jest zawodowy sukces, rodzina staje się czymś drugorzędnym, ponieważ oznacza konieczność ograniczania własnej konsumpcji, co nie jest dobrze widziane w świecie konsumpcji. Kobieta konsumentka powinna być wiecznie piękna, młoda i osiągać sukces na polu zawodowym. Kobieta konsumentka zawsze piękna i odpowiednio ubrana nie ma czasu na refleksję nad swoim życiem. Poczucie szczęścia kupuje - każdy zakup pięknego przedmiotu powinien czynić ją szczęśliwą; podobnie zresztą jak mężczyznę - konsumenta. W świecie konsumpcji nie ma zbyt dużo miejsca na refleksję nad sprawami ważnymi. Świat konsumpcji ogranicza się do rzeczy i wartości materialnych, nacisk kładziony jest na to co użyteczne i piękne. Dlatego kobieta stale jest pod presją bycia piękną i młodą, nie może być zmęczona i nie wolno jej źle wyglądać, ponieważ bardzo dużo wówczas traci. Aby mieć znaczenie w świecie konsumpcji kobieta powinna być piękna, czyli szczupła i młoda. Kobietę w świecie konsumpcji określa ciało, a nie wiedza, umiejętności i kompetencje. Podporządkowanie zasadom świata konsumpcji czyni z kobiety ładnie opakowany przedmiot. Szczęście na miarę świata konsumpcji kobieta konsumentka osiąga jedynie chwilowo, wraz z upływem czasu i naturalnymi procesami starzenia się będzie dla kobiety - konsumentki w świecie konsumpcji coraz mniej miejsca.

Słowa kluczowe: kobieta, społeczeństwo konsumpcyjne, piękno.

DOI:10.7862/rz.2016.hss.70

Przestano do redakcji: wrzesień $2016 r$.

Przyjęto do druku: grudzień 2016 r. 